\title{
Innovation of Community Potential Development in Khlong Luang district, Pathum Thani province
}

\author{
Pinyapat Nakpibal $^{1}$, Metharat Chantanee ${ }^{2}$ \\ ${ }^{1}$ Faculty of Management Sciences, Valaya Alongkorn Rajahat University under the Royal Patronage \\ ${ }^{2}$ Faculty of Management Sciences,Phranakhon si Ayutthaya Rajabhat University \\ Phranakhon si Ayutthaya. \\ ${ }^{1}$ boon25552555@gmail.com, ${ }^{2}$ Metharat18@gmail.com
}

\begin{abstract}
This research had the following purposes :1) to study the participatory community potential; 2) to search for innovation of community potential development; 3 ) to study the impact of innovation on community in Khlong Luang district, Pathum Thani province. The data was collected by in-depth interviews, group discussion and SWOT analysis from key informants, such as the community leader, the chairman and the members of career group and community-based tourism group. The result showed that the community leader was a professional agriculturist, a positive and systematic person as well as having a sweeping vision. Moreover, the community worked together to utilize the resources and solve the problems. The agriculturists in this research area also took the Philosophy of Sufficiency Economy and the new theory of agriculture to develop the community and showed the way of living with community based on "Home, Temple, School". There was a sufficiency economy learning center with the government sponsorship. The innovations for community potential development were product and service innovations, marketing innovation and process innovation including the impact of innovation on community which was teamworking. Community networks were established and the income of the community was increased.
\end{abstract}

Index Terms

Innovation, Community Potential Development, Participation

Article Received: 10 August 2020, Revised: 25 October 2020, Accepted: 18 November 2020

\section{Introduction}

Thailand enhances competitiveness to develop the country's potential by "Further Development of the Past" looking back at its economic roots, identity, culture tradition ,the way of life and the highlights of various natural resources as well as the comparative advantage of the country in other areas, applied in combination with technology and innovation in accordance with the context of the modern world economy and society. "Modernization" to pave the way for the future through the development of the country's infrastructure in various dimensions, including transportation networks, the establishment of scientific basis, technology and digital to facilitate the development of industries and services in the future. Also, "Creating new value in the future" enhancing entrepreneurial potential and developing a new generation including adjusting the business model to correspond to the market demand [1], [2] strengthening business competitiveness and economic foundations to promote the learning process and participation of the people as well as build capacity and strength to generate more careers and income for the community. It is necessary to conduct the spatial development for the community to access professional development including creating a community income and promoting community tourism to reduce the inequality of a society that focuses on generating income and economic strength as well as upgrading the product including developing a variety of marketing channels to increase the income of the community.[3]

The development of the country puts an emphasis on innovation by changing products or services from ideas, methods and knowledge to make a difference, innovate new processes, or new products that creates value-added for economic benefits. It is the key to the Thailand 4.0 model to increase competitiveness to achieve the goals according to the Twenty-Year National Strategic Plan. The beginning of innovation development is in the private sector; however, there are many successful public innovations in overseas government sector. This is the result of cooperation between all departments, as well as in the business sector with an opening innovation strategy, allowing individuals from various agencies to help develop innovation. This will result in a leap development in the short time. [4]

The cooperation process is based on shared values that is not only the profit of the private sector. [5], It is value-driven innovation. It is the value generated by sacrificing their resources to create benefits, particularly in solving the problems of the world that is more complex today. This is an important expectation of "Social innovation" that will bring benefits and happiness in accordance with the meaning of the access level of Sufficiency Economy which could be greatly applied for living. [6]

The development of community potential is created by the community awareness of participation and building problem solving potential in community members that can rely on themselves and lead to sustainability. [7] In addition, in Pathum Thani province, there are policies and plans that strengthen the production process as well as the agricultural and food process to be completely safe. There are also some of tourist attraction developments and tourism and marketing activities for career opportunities and incomes to the local people in participatory method. In Rajabhat Valaya Alongkorn university under the royal patronage, the researches and innovations are applied to tackle local problems with the means of bringing innovations resulting from the use of knowledge in various disciplines to be 
integrated to create something new to happen for the benefit of society and economy. It can increase the value of new developments through searching, implementing and learning to create a strong basic knowledge and could be used to develop resources, wisdom, agricultural products to be effective and added value. The result of the use of innovation in the community creates good ideas of the community and also the application of local wisdom which are the management of community capitals such as resources, productivity, and knowledge. [8]

Khlong Luang District is an area where Valaya Loong Rajabhat University under the royal patronage provides academic service to the community.It is located nearby Bangkok and it is convenient for transportation. With continuous development in the industry and agricultural sector, there are important agricultural products such as Pathumthani fragrant rice, mushrooms, mango, short lifecycle crops, medicinal plants, farming, gardening and animal husbandry in addition to the development of the environment and the management of natural resources to become a livable and sustainable community. From the above information, it can contribute to further the agriculture part to study and research on "Innovation of Community Potential Development", which recognizes the importance of education in participatory community potential and also the searching innovation in Community Potential Development and the study the impact of innovation on the community to reduce social inequality with the distribution of income that causes the community strength as well as having learning and participation in the sustainable development of the community.

\section{Research Objectives}

The objectives of this research article were 1) to study the participatory community potential in Khlong Luang area, Pathumthani Province 2) to search for innovation in community potential development in Khlong Luang District ,Pathum Thani Province., and3to study the impact of innovation on communities in Klong Luang District, Pathumthani Province

\section{Research Methods}

\section{Scope of research}

"Innovation of Community Potential Development", is a qualitative research. The target group was the main information providers who were the group of people selected from the right livelihood group, community enterprise and the OTOP Nawatwithi tourism community in the area of Khlong Third Sub-district, Khlong Fifth Subdistrict, Khlong Sixth Sub-district, Khlong Luang District including the chairman of the board, members and related persons. The data was collected by in-depth interviews, group discussion and SWOT analysis on the strengths, weaknesses, opportunities and obstacles of the community arising from factors within the community which was caused by factors within the community and outside the community. Then searching for innovation of community potential development in Khlong Luang District
Pathumthani Province was a new concept, and methods of operations and services which were the result of the creation, enhancement, extension or application of knowledge as a tool for creating new things that occurred for social and economic benefits, such as innovation, products and services. Process innovation and marketing innovation [9] [10] [11] [12] and to study the impact of innovation on communities in Klong Luang District. Pathumthani province, including economy, society and environment.

\section{A. Research Design}

The researcher scope (a) Scope of content, innovation, community potential development, participation and social changes. (b) The area was the community, Klong Luang District. Pathumthani Province. (c) Population Scope, Population:The research team collected population data divided into 3 groups :First group: people living in Klong Luang District. Pathumthani Province,Second group : group of community leaders, administrators of local administrative organizations and government agencies involved. Third groups, occupational groups, community tourism groups (d) Sample group, First group: group of people living in Klong Luang District Pathum Thani Province around 12 people. Second group: of community leaders, administrators of local administrative organizations and government agencies involved around 12 people.Third groups: community tourism groups around 12 people.(e) Sampling method using proportional sample size. by systematic sampling, according to the location of Klong Luang district Pathumthani Province, namely Khlong third Sub-district, Khlong FifthSub-district, Khlong Sixth district.[13] (f)Instrument included in-depth interviews. Nonparticipatory observation, specific groups discussion, SWOT analysis as well as organizing a community forum on participatory community potential, searching for innovation in community capacity development and the impact of innovation on the community. (g) The qualitative data analysis included the content analysis, the triangulation method from informants relating to participatory community potential, searching innovation in community capacity development and the impact of innovation on the community

\section{B. Research Process}

Research process of this research has developed into 4 steps were shown in Fig. 1.

\begin{tabular}{|l|l|l|}
\hline $\begin{array}{l}\text { The study of } \\
\text { Community } \\
\text { Potential }\end{array}$ & $\begin{array}{l}\text { The study of } \\
\text { innovation for } \\
\text { Community } \\
\text { Potential } \\
\text { Development }\end{array}$ & $\begin{array}{l}\text { The impact of } \\
\text { innovation on } \\
\text { community }\end{array}$ \\
\hline $\begin{array}{l}\text { 1.SWOT } \\
\text { Analysis } \\
\text { 2.Contextual } \\
\text { survey }\end{array}$ & $\begin{array}{l}\text { 1. Interviewing } \\
\text { group Specific } \\
\text { discussion. }\end{array}$ & $\begin{array}{l}\text { 1. Civil Society } \\
\text { Forum } \\
\text { 2.Non- } \\
\text { participatory } \\
\text { observation }\end{array}$ \\
\hline
\end{tabular}

Fig.1 Research process for Innovation of Community

Potential Development in Khlong Luang district, Pathum Thani province 
The researchers studied the potential of communities in Khlong Third Sub-district, Khlong Fifth Sub-district, Khlong Sixth Sub-District, Khlong Luang District Pathumthani Province by surveying the community and SWOT analysis, then studying innovation and community potential development from interviews, specific group conversations and non-participatory observation together with studying the impact of innovation on the community as well as creating a community forum with non-participation observations

\section{Results}

Innovative research result for the development of participatory community potential in Khlong Third Subdistrict, Klong Fifth Sub-district and Klong Sixth Subdistrict, Klong Luang District Pathumthani Province consists of community potential, community development innovation and the impact of innovation on the community as follows.1) Community potential is the realization of value and the preservation of art, culture and wisdom which is unique to the local area [14] including community leaders, community resources and community involvement. The results of the study are presented in Table 1.

Table 1: Community potential

\begin{tabular}{|c|c|}
\hline & Community potential \\
\hline $\begin{array}{l}\text { 1.Community } \\
\text { potential }\end{array}$ & $\begin{array}{l}\text { Community leaders include village chiefs } \\
\text { : Pooyai Rungnapa Kerdtham, Kamnan } \\
\text { Srinuan Thipaphongphakaphan and Mr. } \\
\text { Adul Wichianchai has knowledge of } \\
\text { organic agriculture to support careers and } \\
\text { provide extra income of the people in } \\
\text { needs such as reed weaving, processing } \\
\text { agricultural products and helping people. } \\
\text { In addition, Pooyai Rungnapha has } \\
\text { positive thoughts and minds. Kamnan is } \\
\text { a positive thinker, systematic thinker, had } \\
\text { broad vision. "People are the foundation } \\
\text { for living and developing into the future } \\
\text { with stability and balance according to } \\
\text { the philosophy of sufficiency economy or } \\
\text { "following in the father's footsteps" } \\
\text { and also Kamnan has appropriate } \\
\text { personality, } \\
\text { confidence, polite speech, good mood, } \\
\text { calm and be a giver }\end{array}$ \\
\hline $\begin{array}{l}\text { 2.Community } \\
\text { resources }\end{array}$ & $\begin{array}{l}\text { Community resources: the communities } \\
\text { have important resources, namely water, } \\
\text { soil that people in the community can be } \\
\text { used together as well as having resources } \\
\text { created by the community and made } \\
\text { from agriculture and local wisdom about } \\
\text { the cultivation of rice, organic } \\
\text { vegetables, bamboo, kim sung, sugarcane } \\
\text { cane juice, pandan juice, dried bananas, } \\
\text { Thong Muan product, woven reed mat, } \\
\text { bike and turbine baler, dried mango } \\
\text { paste, chili sauce and rice cracker in } \\
\text { various flavors. }\end{array}$ \\
\hline 3. Community & involvement: \\
\hline
\end{tabular}

involvement

correspondence to the reason that 3 ) Community involvement with government officials works well together with the involvement between the government officials and community meets the needs of the community in order to organize tourism activities and create careers for the people.

SWOT analysis: Overview of communities in Klong Luang District, community potential is the capability of the community to jointly implement activities by bringing resources such as agricultural products local wisdom etc. to benefit the community and generate income for self-reliance and strength which people in the community have to realize and also preserve for the art, culture and wisdom as a local identity[28] consisting of community leaders, community resources and community participation as follows, a) In khlong third sub-district, community leader is Pooyai Rungnapha Kerdtham, village chief who is well-versed in the professions of the people to help the people in trouble and supports people to earn extra money by promoting careers such as weaving reed mats, processing agricultural products such as dried bananas. sugarcane juice, pandan juice, eclair snack, etc. Pooyai Runnapa is a person with positive thoughts and minds. "People are the foundation of living and are developed into a stable and balanced future according to the sufficiency economy philosophy". Also, she has appropriate personality such as self-determination, confidence, polite speech, good mood, calmness and being a giver. b) The community has important resources, water, soil, which can be used by people in the community. In addition, there are resources created by the community and produced from agricultural production and local wisdom; for instance, rice, organic vegetables, Kimsung bamboo, Cochinchin gourd, sugar cane, cane juice, pandan juice, dried banana, Tong Muan snack, woven reed mat, bike and turbine baler, etc. Government officials are the intermediary between the community and government agencies to meet the needs of the community and the entrepreneurs of the tourism community bring products and services to offer tourists and sell them together with wearing Thai clothing. Pooyai Rungnapa supports the additional occupations with the knowledge of sufficiency economy philosophy and conservation of local wisdom. There are activities relating to sufficiency economy philosophy and local wisdom as well as the maintenance and improvement of tourist attractions to attract more tourists to visit the Klong sixth sub-district community. Regarding to the planning to make a decision for the operations, there are regular meetings which are held normally about organizing activity and travel services. The villagers have embraced the philosophy of sufficiency economy and the new theory of agriculture with the livings with harmony. The majority of people has careers in farming and trading with simple lifestyles. The community has received academic sponsorship from the government sector and educational institutions to promote and support the economy, utilities and public health. The government encourages the people to live in a modest way of livings according to The King Rama IX, as well as exchange social and technological learnings with government agencies. In khlong fifth sub-district, Kamnan Srinual 
Tipaphongphakaphan has knowledge about the occupations of the people. She helps the people in needs and supports the raising of special income of the people as well as promotes a career in organic farming and processing agricultural products. Regarding to thoughts and minds: Kamnan Srinuan is a positive thinker, systematic thinker, has broad vision, "People are the foundation for living and developing into the future with stability and balance according to the philosophy of sufficiency economy. She also has the right personality, such as self-determination, confidence, patience, polite speech, and being a giver. The community has important resources, namely water, soil that people in the community can use together. In addition, there are community-generated resources and made from agriculture and local wisdom, such as organic rice, sugar cane, sugar cane, crispy noodles, curry paste, dried banana, Thong Muan product, etc.

Government officials are intermediary to the needs of the community and to meet the needs of the community. The entrepreneurs of the tourism community bring products and services to offer tourists and sell them together with wearing Thai clothing. Kamnan Sri Nuan supports the occupations for the villagers as well as the knowledge of sufficiency economy philosophy and conservation of local wisdom. There are activities relating to sufficiency economy philosophy and local wisdom as well as the maintenance and improvement of tourist attractions to attract more tourists to visit the klong sixth sub-district community.

The villagers in the community who have a farming career have embraced the philosophy of sufficiency economy and new atheist agriculture. In addition, the community has been promoted academically, economically, utilities and public health. The sale of community products is distributed through individuals, government agencies, social media. The government encourages the people to live in a modest way of livings according to The King Rama IX, as well as exchange social and technological learnings with government agencies.

In khlong sixth sub-district, there is a leader that is recognized by neighbors named Mr. Adul Vichienchai who has wide knowledge about the organic farming. He helps the people in trouble and supports the neighbors to earn some extra money and promote careers. Regarding to thoughts and minds: he has a systematic mindset and wide vision "Following in the footsteps of the father". The community has important resources; for instance, water and soil that people in the community can share their benefits. In addition, there are resources created by the community and produced by agriculture and local wisdom, such as rice, organic vegetables, dried bananas, dried mango paste, rice crackers and mushrooms in variety of flavors etc. Government officials are intermediary to the needs of the community and to meet the needs of the community. The entrepreneurs of the tourism community bring products and services to offer tourists and sell them together with wearing Thai clothing. Mr. Adul supports the occupations for the villagers as well as the knowledge of sufficiency economy philosophy and conservation of local wisdom. There are activities relating to sufficiency economy philosophy and local wisdom as well as the maintenance and improvement of tourist attractions to attract more tourists to visit the klong sixth sub-district community by planning and making a decision for tourism.

The villagers who have farming careers, adopting a philosophy of sufficiency economy and new theory of agriculture. The community shows the way of living with community based on "Home, Temple, School". The community lives in harmony with others and has a learning resource for the sufficiency economy. The government sectors and educational institutions promote and support the community development. The community products are distributed to individuals, government agencies by social media, smart framer networks, young smart framers and Khok Nong $\mathrm{Na}$ model. The community shows the importance to create "Well-Being"

\section{Innovation of the development of community potential}

Innovation is a new concept, method, new method of operation and the services is the result of the creation, enhancement, extension or application of knowledge as a tool for creating new things that occur for social and economic benefits, such as, products and services innovations, process innovation and marketing innovation [15] [16] [17] [18] are as follows.

Table 3 shows the innovation of development of community potential in Klong Luang District, Pathum Thani Province

\begin{tabular}{|l|}
\hline Innovations \\
\hline 1.Products \\
and Services \\
innovations
\end{tabular}
Results

Creating value to increase the productivity of the community includes organic chicken eggs for making éclair dessert, community branding, sugar cane juice, pandan juice, rounded orange juice drink, soil for planting with Loong-Pooyai formula, fish- extracted organic fertilizer with Loong-Pooyai formula, herbal crispy noodle, various chili pastes, various shaped bags.

-The use of wisdom to create community products is described as follows: the reeds for weaving the colored reed mats from the roots, core, the bark, the flowers and the trunks of various kinds of trees for the creation of the "dried lotus" lotus.

-Innovative technologies include bike water pumping for agriculture, essential oil extracted from orange peel.

\begin{tabular}{l|l} 
2.Process & - The village headman and the people
\end{tabular}
innovation collaborate to develop the Sufficiency Economy Philosophy learning center.

- The process of weaving reed mats from reed planting, reed cutting, reed slitting in strips and sun drying. When dried, it is used for natural dyeing for weaving in various mat patterns

- People jointly determine how to maintain natural resources and the environment in the community that tourists can experience the smell of nature. The air is free from pollution and the leaves that photosynthesize release oxygen "It allows the tourists to get fresh air"

- Demonstration process of making Mee 


\begin{tabular}{|c|c|}
\hline & $\begin{array}{l}\text { Krob (crispy noodle) for those who come } \\
\text { to study and visit } \\
\text { - The process making Thong Muan Krob, } \\
\text { making dried banana in solar } \\
\text { oven,extracting essential oils from the } \\
\text { orange peel,producing spherical orange } \\
\text { juice,producing herbal drinks and growing } \\
\text { salad vegetables on the table. } \\
\text { - The development of Khok Nong } \mathrm{Na} \\
\text { Model }\end{array}$ \\
\hline $\begin{array}{l}\text { 3.Marketing } \\
\text { innovation }\end{array}$ & $\begin{array}{l}\text {-The market orientation for healthcare } \\
\text { customers } \\
\text {-The variety of products such as Thai } \\
\text { desserts, beverages, organic vegetables, } \\
\text { handicrafts } \\
\text {-The upgrading of community products to } \\
\text { be certified and stylish for packaging } \\
\text { including having a brand that indicates the } \\
\text { community identity together with } \\
\text { increasing online distribution channels }\end{array}$ \\
\hline
\end{tabular}

\section{The impact of innovation on communities}

The impact of innovation on community in the economic aspect is to improve operational efficiency. It reduces production costs, and creates value and prominence in community products. The sale of community products using information technology which is a new and fast service is competitive to the business community and survive under the current economic challenges. This enables the community business to achieve market success because it meets the needs of customers continuously and adjust customer's attitude for the product quality awareness as well as brand recognition. The viral marketing is introduced to others and new customers and there are new customers continually. Regarding to the social aspect, there is a good relationship between the community and the visitors. The good leaders who have a broad vision, positive thinking, systematic thinking create social equality, resulting in the higher exchange of people in the community. People can live moderately according to the sufficiency economy philosophy, "Following in the footsteps of the father", and a community network is developed as well as strengthening agricultural careers, creating productive values and community resources along with upgrading the service level of the community to be more professional. Regarding the environmental aspect, the people have ownership and more cares for places. There is a system to eliminate municipal waste and reduce environmental degradation such as soil, water and trees.

\section{Discussions}

Innovation for the development of participatory community potential development of community engagement potential in Khlong Third sub-district, Klong Fifth sub-district and Khlong Sixth sub-district. Khlong Luang District, Pathum Thani province consists of community potential, innovation for community potential development and the impact of innovation on the community as follows:

1.Community Potential in Khlong Third sub-district, Klong Fifth sub-district and Khlong Sixth sub-district. It was found that community leaders, including Pooyai Rungnapa Kerdtham, Kamnan Srinuan Thipaphongphakaphan and Mr. Adul Wichianchai were knowledgeable persons in organic agriculture and sufficiency economy philosophy to provide professional supports to the people in community. They also had good minds, systematic thinkings, far-reaching visions. The important community resources were water, soil that people in the community could share and maintain, while cooperating with government officials to develop communities to organize tourism activities and to create careers for the people.

The community had its strengths which could be described that the villagers of the agricultural profession adopted a sufficiency economy philosophy and a new theory of agriculture, which was a learning resource for the sufficiency economy philosophy. The community lived with harmony and showed the way of living with community based on "Home, Temple, School". The community access was convenient and safe, supported by the government sectors, and educational institutions to promote and support the economy, utilities and public health. Those encouraged people to live their ways of lives sufficiently according to the initiative of King Rama IX. There were more exchanges for social and technological learnings with government agencies. There were Smart framer and Young smart framer networks which were consistent with the research results of [19] found that factors that promote the strength of the community in the municipality of Pak Kret Nonthaburi province were as follows: 1) Dedicated community leaders and good human relations 2) Community members accept the role of community directors 3 ) Communities have high self-reliance potentials 4) Communities and municipalities have good cooperation.

Weaknesses were found that some families were poor. Regarding the marketing management, community products were less modern and insufficient identities, low prices and inadequate amenities to meet the needs of tourists along with obstacles to the lives of the people. There was a high cost of living, high debt, low agricultural productivity, High cost of agriculture. There was also a high market competition. In addition, the way of lives of the people today was not keeping up with the changes in technology and society. In line with the research results of [20], it was found that border communities, permanent border crossing point, Chong $\mathrm{Phu} \mathrm{Du}$, Ban Khok District, Uttaradit Province. There were guidelines for solving problems of government agencies and local people by linking human resources with the economy.

\section{Innovations for community potential development in Khlong Fifth sub-district and Khlong Sixth sub-district, Klong Luang District, Pathumthani province found that}

1) Innovative products and services were as follows (1) Creating value-added products of the community by processing such as organic chicken eggs, eclair dessert, community branding, sugar cane juice, pandan juice, rounded orange juice drink, soil for planting with LoongPooyai recipe, fish-extracted organic fertilizer with LoongPooyai formula , herbal crispy noodle, various chili pastes , various shaped bags, Thong Muan product, solar-dried banana, Bhu Than mushroom cube, Bhu Than mushroom 
cracker. Chiffon Bhu Than mushroom. (2) Bringing wisdom to create community products such as papyrus, weaving colored-reed mat from the roots, bark, fruit, flowers and trunks of various types of trees, including creating "dried lotus" work. (3) Renewable energy is a bicycle pumping water for agriculture and (4) Science is the extraction of essential oils from the orange peel and making spherical orange in correspondence with the concept of [21] discussed the products that reflected the efficiency of the organization's new product development.

2) Process innovation ; for instance, the village chiefs and the people cooperated to develop the Sufficiency Economy Philosophy Learning Center as well as maintaining natural resources and the environment in the community that would benefits for the tourists who could experience the smell of nature that free from pollution and see the leaves photosynthesize and release oxygen for "Allowing tourists to get fresh air". The process of weaving the reed mat , process of making crispy noodles, process of making crispy Thong Muan products, process of making rounded- orange juice, process of the production of herbal drinks and growing salad vegetables on the table, the development of Khok Nong Na model in accordance with the concept of [2] discussed the manufacturing process that was different from the old method in correspondence with the research of [23] found that at present, the community enterprise groups have created the most innovative wisdom which supports the sufficiency economy in the aspect of process innovation.

3) Marketing innovations include (1) targeting specific markets for health care customers. (2) Product diversity, such as Thai desserts, beverages, organic vegetables, handicrafts and (3) Upgrading the community products to be certified and stylish for packaging together with having a brand that indicates the community identity as well as increasing online distribution channels in correspondence with the research by [24] it was found that marketing innovations that affect buying behavior and brand loyalty are product diversity and customer orientation to raise the level of herbal products to be more interesting and known as well as increasing the competitiveness in a sustainable way.

\section{The impact of innovation on the community}

1) economic aspect: the community enhanced operational efficiency which could reduce production costs; create value and prominence in community products; sell community products using information technology as a new, fast service. The community was capable of competing with community businesses and survives under the current economic challenges. This enabled the community business to achieve market success because it met the needs of customers continuously and adjusted the customer's attitude for the product's quality awareness as well as brand recognition. The viral marketing was introduced to others and new customers and there were new customers continually in accordance with the research of [25] found that the creation of innovation to enhance the economy for agriculture, community enterprises and small to mediumsized enterprises in the provincial level. 2) Social aspect: there is a good relationship between the community and the visitors. The good leaders also had a broad vision, positive thinking, systematic thinking, creating the social equality that would lead to higher exchanges of people in the community together with following the sufficiency economy philosophy, "following in the footsteps of the father", and the community network was established to develop and strengthen farmers to create value for profit and community resources, while improving the service of the community to be more professionally in accordance with the research of [26] that the community of Ban Si Sanphet, there was a variety of traditions, cultures and nationalities. It had a long history of archaeology and the recognition of cultural value and tradition to the youth. 3) Environmental aspect : people have more ownership and more cares for places. In addition, there was the system of organizing community waste and reducing environmental damage such as soil, water and trees in accordance with the research of [27] found that the community of Hua Ngam sub-district, Phan District, Chiang Rai province, initiated the "People's charter for people in Hua Ngum", which is a productivity of ideas, process and the cooperation from multiple parties, clearly expressed and translated into concrete action It the model driven development of the rules of the community including the maintenance of natural resources and the environment in the community.

\section{Recommendations}

\section{A. Suggestions for applying the research results}

Research results found that the communities had weaknesses as follows: 1) Economic aspect: some families were poor and the marketing management with the community products was less modern and lacked identity, low prices and inadequate amenities to meet tourist needs. There were a cost of living, high debt, agricultural productivity, low prices, high cost of agriculture. There was high market competition. Therefore, agriculture development should be developed to create values by applying innovations in the agricultural sector which could be the country's goal ; for instance, the agricultural identity, agricultural safety, bio agriculture, processed agriculture and smart agriculture to increase productive efficiency both in terms of quantity, quality and product variety including raising the income level, reducing expenses and risk factors in farming for farmer as well as maintaining biodiversity and local wisdom 2) Social aspect: It was found that the lifestyle of the people at present does not keep up with the changes in technology and society. Therefore, the community should focus on technological innovation to develop new innovations all the time

\section{B. Recommendations for Further Research}

1 Should study the development of community the development of community enterprise groups.

2. Should study the development of community the development of community enterprise groups

\section{Conclusion}

In conclusion, Innovation for the development of participatory community potential in Khlong Third subdistrict, Khlong Fifth sub district, and Khlong Sixth Sub- 
district, Khlong Luang District Pathumthani Province studied the potentials of communities in Khlong Third subDistrict, Khlong Fifth sub-District and Khlong Sixth subdistrict, Khlong Luang District Pathumthani province found that the community leaders were knowledgeable and capable to transfer knowledge on organic agriculture and the sufficiency economy philosophy. They provided career supports for people with good minds, systematic thoughts, wide visions. Regarding the important community resources, there were water, soil that people in the community could use together and maintain. In addition, the people cooperated with government officials to develop the community in organizing tourism activities as well as creating a career for the people.

The community had its strengths; for instance, the villagers whose occupations were agriculturists followed the sufficiency economy philosophy and the new theory of agriculture, which is a learning center for the sufficiency economy philosophy. The community also showed harmony and the a simple way of lives that relied on the community in the style of "Temple, Community and School" On the other hand, there were some weaknesses ; for instance , some families were poor and the marketing management in community products was less modern and lacked their own identity, low prices and inadequate amenities to meet the needs of tourists along with the obstacles to the lives of the people. There were a high cost of living, high debt, low agricultural productivity and high cost of agriculture. There was high market competition. Also, the way of lives of the people today is not keeping up with the changes in technology and society.

Innovation of community potential development in Klong fifthsub-district and Khlong Sixth sub-district , Khlong Luang found that 1) Product and service innovation were to create value to increase community productivity by processing the local wisdom to build community products, using the renewable energy and scientific knowledge.2) Process innovations include leaders and people working together to develop sufficiency economy philosophy learning centers, the preservation of natural resources and the environment in the community, weaving reeds procedure, crispy noodle procedure crispy Thong Muan procedure, the production of rounded orange juice, the production of herbal drinks, and the planting of salad vegetables on the table and the development of the Khok Nong $\mathrm{Na}$ model.and3) Market innovation was aimed to marketize only for healthcare customers. There was a wide variety of products including the upgrading of the community products to meet standards.

The impact of innovation on the community was as follows 1) Economic community enhanced the operational efficiency. There was a reduction in production costs and also creating values and prominence of community products together with the distribution of community products using information technology and competitive community businesses.2) Social aspect: there was a good relationship between the community and the visitors. The leaders had a broad vision, positive thinking, systematic thinking, creating social equality that would lead to higher exchanges of people in the community. The community lived modestly according to the sufficiency economy philosophy. "Following in the footsteps of the father" and built a community network while enhancing the service of the community with greater professionalism. and 3) Environmental aspect: people had more ownership and cares for places. There were community waste management system and reducing environmental destruction such as soil, water and trees.

\section{References}

[1] Secretariat of the National Strategy Committee Office of the Economic Development Board and National Society (2018). National Strategy 20 years 2018 2037.Bangkok: Secretariat of National Strategy Committee Office of the National Economic and Social Development Board.

[2] Office of the National Economic and Social Commission (2017). The study and analysis of economic, social and cultural factors that support the strength of communities Bangkok: Office of the National Economic and Social Commission.

[3] Department of Community Development (2018). A guide to establish learning processes and preparing effective community plans 2018, Bangkok: Department of Community Development. Ministry of Interior.

[4] Hudson, R; \& Sullivan, TA (1995). The Social Organization of Work. 2nd ed. New York:Woodsworth.

[5] Wanna Appetwong (2016). Social entrepreneurship based on buddhist economics:A case Study of Na Muensri Weaving Group. at the 10th national economist conference, Duangtawan Hotel. Chiang Mai University.

[6] Apichai Pansen (2017) Sufficiency Economy The genius and grace of the King Rama IX. Pathumthani: Rangsit University

[7] Suthida Bua Sukkasem. (2011). Guidelines for developing the role of community councils in promoting the strength of the community. A case study of Nong Pradu Sub-District, Lao Khwan District, Kanchanaburi Province. Master of Social Science Thesis. Department of Social Work Bangkok: Thammasat University. 
[8] Secretariat Office of Community Enterprise Promotion Board (2012). Community enterprise registration manual.and community enterprise network Retrieved 10 May 2012 from http://www.sceb.doac.go.th

[9] Naidoo, V. (2010). Firm survival through a crisis: The in fluence of market orientation, marketing innovation and business strategy. Industrial Marketing Management. 10. 110-122.

[10] Organization for Economic Co-operation and Development. (2004). OECD Principles of Corporate Governance. Retrieved December 25, 2015, from http://www.oecd.org.

[11] Schumpeter, J. A. (1934). The theory of economic development: An inquiry into profit, capital, credit, interest and the business cycle. Cambridge: Harvard University Press.

[12] Salter, A., \& Tether, B.S. (2006). Innovation in Services. Through the looking glass of Innovation studies. London: Tanaka Business School.

[13] Kalaya Vanichbancha (2010). Statistics for research. Bangkok: Chulalongkorn University.

[14] Mill, R. \& Morrison, A. M. (1992). The Tourism System.: and Introductory Text. New Jersey: Prince Hall Intentional Inc

[15] Naidoo, V. (2010). Firm survival through a crisis: The in fluence of market orientation, marketing innovation and business strategy. Industrial Marketing Management. 10. 110-122.

[16] National Innovation Agency (2015). Innovation ... Thai people can do it from idea to real practice. Bangkok: National Innovation Agency.

[17] Rapeepat Sukkasem (2016). Factors that affect the strength reinforcement of community. A case study of the community in the Pakkred municipality, Nonthaburi Province. Independent Study of the Master of Religious Studies, Department of Public Administration and Public Affairs Thammasat University.
[18] Putinan Bunruang (2017), A transformational leadership model for resource management and environment of the Green Economic Community in Uttaradit Province. Doctor of Philosophy (Educational Leadership and Human Resource. Development) Chiang Mai University.

[19] Teerasak Aun Aromlert et al. (2015). Development of a model for creating innovation wisdom for sufficiency economy to enhance sustainable competitiveness of community enterprises, product processing groups Provincial groups in the lower central region Silpakorn Education and Research Journal. 7 (2), 79-92.

[20] Boonsom Lechayakittikorn (2015). Marketing innovation for herbal products. Master of Science thesis. Department of Technology Management. Thammasat University.

[21] Wichian Foi Phikul et al. (2018). Innovation to develop areas to support agricultural capacity and to upgrade the foundation of economy in Nakhon Ratchasima. Nakhon Ratchasima Rajabhat University.

[22] Linda kenmar et al. (2018). Innovation from plants and local wisdom for economic development in community at Ban Si Sanphet. Bansomdejchaopraya University.

[23] Prayoon Imiwat et al. (2018). Localization Concept: Innovation in Community Management at Hua Ngom Subdistrict Phan District, Chiang Rai Province. Administrative Journal. 7 (2), 173-174. 